AP: Ontine Journat in Public Archaeology Volume 6 - 2016 p. 75-116

\title{
Droping the Trowel:
}

Three Discourses and One Creative Archaeology

\author{
José A. MARMOL MARTÍNEZ \\ Universidad Complutense de Madrid
}

Received: 25/04/16 - Accepted: 28/07/16

\begin{abstract}
Archaeology offers insight into the values of the contemporary world. From three separate discourses, which address different temporalities and sites, an overarching archaeological narrative has been established, which reflects the role of art and heritage in artistic destruction; education and archaeology as an educational and social tool; and materiality (in the present case, the Chinese pottery sherds in Al-Andalus) in the interpretations and acts of archaeologists. The visual values of archaeology and the role of the archaeological imagination to unify disparate archaeological practices will be explored here. The permeability of the spheres of archaeology and art allow us to explore both archaeological and artistic practices, as well as reflect on universal convictions and on the potentiality of archaeological practice to intervene in social contexts. With all this, archaeology acquires relevance insofar as it is a practice that is able to address the problems of the present day. In line with the so-called 'creative archaeologies', with their experimentation and creation of artistic works (in this case photographic), this paper aims to reflect on new ways to 'see' archaeology, which has never been more necessary.
\end{abstract}

\section{Keywords}

Creative archaeologies, Art, Didactics, China, Archaeological theory 
76 - José A. MÁRMOL - Dropping the Trowel...

\section{Introduction}

If anything characterises a science, it is the approach taken to act upon certain problems. These problems, according to the posthumanities or the new humanities (in our case, the humanities and social sciences), are not required to exist within a historical context. Rather, they can be the actual and urgent matters of the contemporary world, such as the refugee crisis, the war, or poverty, as one percent of the population owns about as much as the remaining 99 percent.

The site of archaeological practice is a point of convergence of different times and experiences that somehow transpire in materiality. The act of 'discovering' meanings is often a secondary concern when we look at the archaeological from a historical perspective, that is, establishing a chronology of events into which the discovered materials are inserted. This method of interpreting the position of the experiences in the chronology sometimes stands in the way of the potential of archaeology as a tool of the present. The past is presented to us as non-place-between the real and the imagined-where extraordinary things occur and flirt with the incredible. There are things and facts that are not anymore

By presenting three different discourses-all chronological, but from an aesthetic point of view instead of logical-the role of the visual in the perception of conventional, mainstream archaeology can be brought to the fore. The burgeoning field of creative archaeology, as it is commonly referred to, is a way of blurring the boundaries between artistic and archaeological practices.

Creative archaeology, however, is not new. Examples of such attempts to blur these boundaries can be found in archaeological meets all over the world (most important conferences already have sessions dedicated to this topic), articles (authors specialising in postprocessualism and archaeological theory, and archaeologists incorporating art into their research), research groups, collectives, museums, and artistic laboratories (the Metamedia Lab at Stanford ${ }^{1}$ is a remarkable example, the Kyoto Art \& Archaeology Forum ${ }^{2}$

1 Metamedia at Stanford. Retrieved from http://humanitieslab.stanford.edu/ metamedia/Home.

2 Kyoto Art \& Archaeology Forum. Retrieved from http://art-archaeology-kyoto.com/. 
is another) in the past twenty years, under postprocessualist approaches and postmodernist practical exercises.

Moreover, the creative perspective in archaeology is allowing us to break the historiographical and methodological boundaries between archaeologies from different countries, bringing practices and common approaches to a field of experimentation and reflection that will be beneficial to archaeological interpretation.

To this artistic perspective-through which new meanings and ways of looking at the archaeological can be decoded by means of feelings and experiences-this paper adds didactic and public perspectives, so as to draw from this theoretical reflection some ideas on interventions in social spaces built on experiences that are visible in the material. It intends to influence the flow of life by suggesting what can make us reflect on our universal convictions, so as to aid in fighting the problems arising from poverty, marginalisation, xenophobia or racism with resilience processes in the present.

The story presented here begins with the visit of a child to an archaeological site, from which three discourses emerge: an archaeological (a soft review of the findings of Chinese ceramics in Al-Andalus), an artistic (the destruction and use of heritage by Chinese artist Ai Weiwei), and a didactic/public discourse (the memory of my team conducting archaeology courses for teenagers in Murcia). The three discourses are interleaved, providing an overview that aims to reflect on the role of academic narratives and the emergence of different ways of 'seeing' archaeology from divergent modes of thought. What emerges as important is the existence of an archaeological aesthetic that largely determines our actions as archaeologists.

In our workspaces, there is much more going on than just ceramics popping up or volunteers filing through trash; there are also hierarchies, aesthetics, conventions, narratives, and metavisions. The mediation between archaeologists and 'raw' data (a dichotomy proposed by Edgeworth 2006) in the development of archaeological practice, where processes of discovery and inscription are interleaved, has qualities of archaeological space that had never before been recorded and analysed in standardised inscription processes. 
The visual is not only a way to record or control the 'projection' of the image that archaeologists display to society, but also a way of producing elements of study to analyse the transformations of materiality in the temporal percolation between past and present. Not only videos, but also sounds and pictures can be used in this regard. Passive videos, sounds and images are also useful, in that they can serve as the basis for producing elements for reflection related to contemporary art, which contribute to a theoretical orientation of what we lose when coming into contact with the memory of the material.

I want to approach these values from the heretic perspective, in the sense proposed by Ricardo Frigoli (2012). In speaking about the emic and etic perspectives when addressing a study of prehistoric peoples, Frigoli introduces two terms to complete the terminology for describe some of the current ways of acting in archaeology: epic and heretic. He defines epic as the vision of the past from an artistic reconstruction, influenced by Stephanie Moser (see, for example, Moser 1998), which is based on feelings. Heretic, meanwhile, refers to more heterodox ways of conducting archaeology such as the implementation of contexts of the present to study the archaeological record (e.g. the William Rathje's Tucson Garbage Project in the 1970s). In the present study, I hold a perspective that is simultaneously epic and heretic. Departing the strictly archaeological (the past), however, has nothing to do with sensory appreciation. More than interpreting the past, new archaeological applications serve to position archaeological practice in the context of the present.

\section{Three discourses and one narrative}

\section{PRESENT}

Near a village, there is a site which is being excavated by a group of people who, they say, have found remains of medieval ceramics. Some days, perhaps less often than they should, they let the locals approach to look at what they're doing, and even take a little time to explain 
with their vocabulary of measures, times, and types, that these brown and green pieces are Islamic ceramics from when the site was an important maritime trade post in the Mediterranean. There are also many children there, because they go with their parents or with the school to see the wonders of archaeology. They have heard how at some point in history this place was very important, but they can't understand what this has to do with the piles of dirt and sherds of pottery that they can see through a mess of bags, papers, and buckets, and the volunteers coming and going. One of those children slips away from the group and approaches a table where, with a methodological order that he surely doesn't understand, there are many bags with a strange puzzle, half-completed, with what looks like a green vase. Among the disorder, on the edge of a plastic chair, the child catches it in his hands. His feet will slip and the responsible adults come running to stop him.

He has a short time to look.

\section{0th-11th CENTURIES AD}

The Caliphate of Cordoba, the main authoritarian force in the middle and south of the Iberian Peninsula, has collapsed and disintegrated into smaller political units called taifa, corresponding to dynastic families with large pieces of power in territories, such as Murcia, Almeria, Denia, Zaragoza, and Badajoz. They are small political cells that inadvertently share trade routes that extend throughout the Islamic world and its eastern borders, from China to Al-Andalus through Fustat (Egypt) and Baghdad (Iraq). Following the demise of the Silk Road, it has become a commercial network that serves to import luxury goods.

In various sources, there are references to the main sea ports and economic centres of Al-Andalus, such as Almeria, Dénia and Seville, charting networks with North Africa, the Middle East and Central Asia (Valdés 1995: 167), Jerusalem, Tyre, Aleppo, and Fustat (Egypt) (Valdés 1991: 323), and in a wider area with more distant places like Yemen, India (Valdés 1991: 323) and, as noted above, with China. 
80 - José A. MÁRMOL - Dropping the Trowel...

\section{0th CENTURY AD}

The Chinese artist Ai Weiwei was the son of a poet who opposed the regime. Due to his works, the poet had been sentenced to enter a labour camp in which he raised his son. It was not until 1993 that Ai was back in Beijing again, after coming into contact with the postmodern avant-garde art of Marcel Duchamp in New York (Ai Weiwei 2012).

Ai became interested in the works of traditional craftsmanship that had been destroyed by the Cultural Revolution (19661976), and started buying antiques and changing their meaning completely. Some of these works consisted of painting Western trademarks, such as the Coca-Cola logo, on ancient urns of the Western Han Dynasty (206 BC-9 AD), creating a new category of art, the ancient ready-made (in line with Duchamp's ready-made) (Figure 1). Interestingly, the police were never especially interested in the destruction of antiquities, which represented Ai's rejection of history announcing his identity change from antique collector to transformer of meanings.

All of Ai's artistic production concerns Chinese culture, society and history. Approaching these values from the perspective of the ready-made allows the viewer to review some convictions of traditional thinking about the role of art and the artist. The materials and the traditional techniques used show a determination to highlight the relevance of its 'Chinese' qualities, while rebelling against the same. According to the artist, history is always a lost part of the "puzzle of everything we do" and "what we are" (Le 2009). For $A i$, aesthetic forms illustrate the artist's relationship with both Chinese culture and traditions, and contemporary art, which explains the ancient-ready-made. 


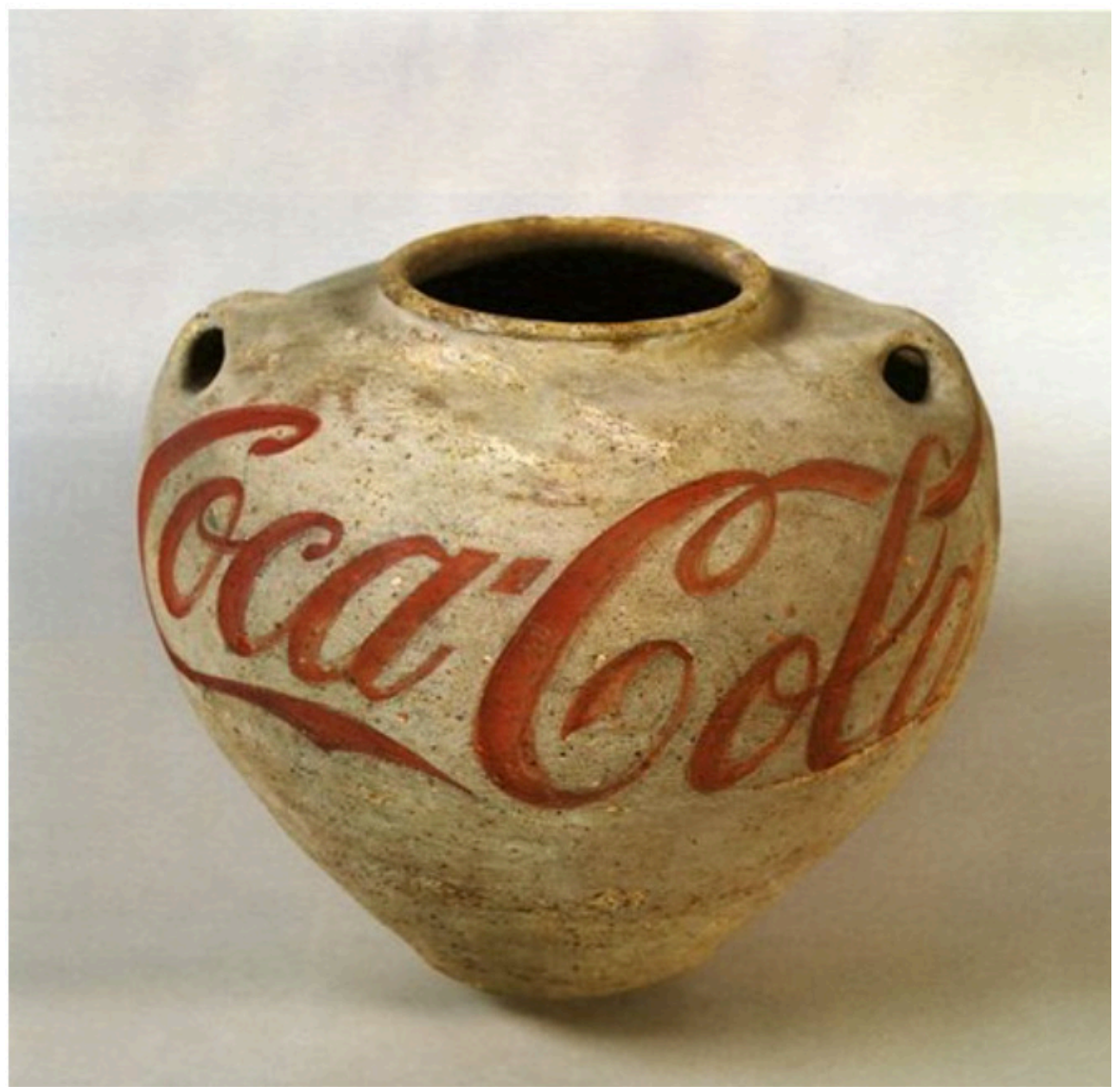

Figure 1. Ai Weiwei. "Han Dynasty Urn with Coca-Cola logo".

\section{1st CENTURY AD}

The simulated excavation is a space where archaeological and educational practices converge. The union of both achieves some objectives in the field of education and the training and experimentation for professional archaeologists. The archaeological methodology is the basis of this performance, adapting concepts discussed in archaeology into a didactic discourse that allow us to view archaeology not as a part of history (in this case, the subject) but as a complete science in itself, with its debates, 
concepts and provocations. Far from building a discourse based on unidirectionality, where those who know more (i.e., the archaeologist and/or teacher) suppress those who know less (i.e., students), they all contribute to its expression and conclusions so as to expand the boundaries of the site. All this is done with the conceptualisation of the excavation as a representation of the past and as a theatre full of archaeological aesthetics.

Simulated excavations have even incorporated tradition in recent years. Usually, they are carried out under the umbrella of courses within schools-high schools (or IES in Spanish) or the summer programmes of public administrations-but with special focus on complementing the teaching of history. The educational aspects provided by this activity (which have long been put into practice; see for example Egea and Arias 2013) have rendered the political and social potential of archaeology invisible. There are examples of simulated excavations occurring in Spain since the 1990 - in the areas of early childhood education, as well as primary or secondary education levels-in cities like Valencia, Zaragoza, Barcelona, Madrid, and Murcia. Outside Spain, this activity has been developed in real sites as part of socialisation, such as in the Amesbury Archer Primary School in Amesbury and St Osmund's Roman Catholic Primary School in Salisbury (Bunyard 2009, from Egea and Arias 2013: 6).

A review of the Spanish examples gives us an idea of the theoretical background that has prevailed in simulated excavations. In the IFP Misericordia in Valencia, the excavation of a prehistoric fake site was developed in 1990 (FP level), and in the IES Sant Quirze in Barcelona local deposits were replicated in a Neolithic and Bronze Age site in 1994.

Following this dynamic, the Institut La Románica in Barcelona carried out an excavation recreating the Palaeolithic and Neolithic periods; in the IES Humanes in Madrid, a megalithic site and an Iron Age necropolis were excavated in 2002; and in the 'El Cigarralejo' Museum of Iberian Art in Murcia, there were excavations of a Bronze Age grave and a Roman level (Gil, Izquierdo, Pérez and Fierrez 1998; Bardavio 1998; Bardavio, Gatell and Molinero 1996; Ramos and Torrico 2006. From Egea and Arias 2013: 5-6). The Roman era is another popular period to recreate (e.g. the CP Virgen de 
la Peña in Zaragoza in 2011). Among these examples we can find highly aesthetic themes, such as Egyptian culture at the Campus Arqueológico Fundació Arqueológica Clos in Barcelona (Egea and Arias 2013: 6).

However, we find examples of the opposite in the Arqueódromo of the Universitat de les Illes Balears for students of history (García, Javalollas, Santacreu and Calvo 2011) or in the Archaeo-drome for students of archaeology at the communitarian center of La Estación ${ }^{3}$ in 2015, and in the IES Beniaján ${ }^{4}$ in Murcia, in June and November 2015 respectively. In these places, the procedures and concepts of the previous experiences and the pre-eminence of history over archaeology in these types of archaeological didactic activities were questioned (Mármol, Muñoz and Marín 2015) (Figure 2).
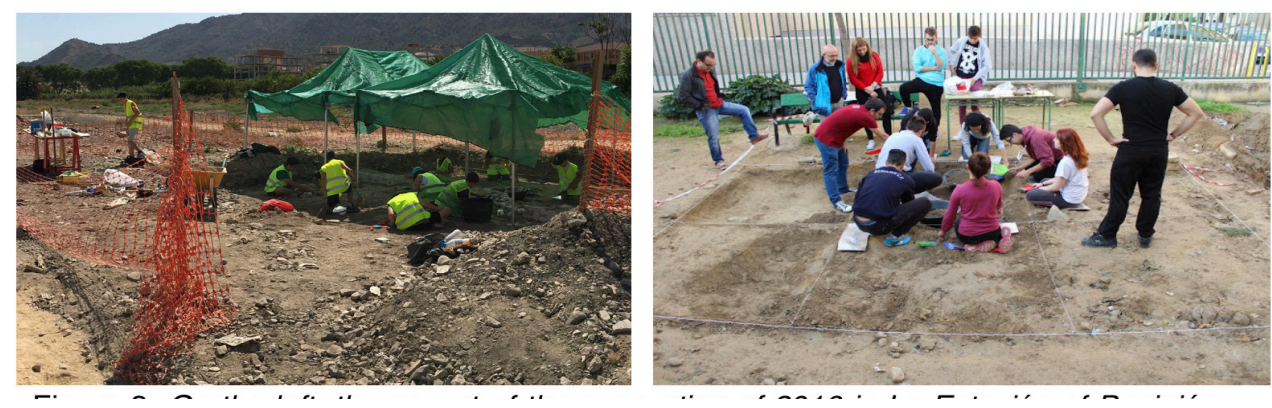

Figure 2. On the left, the aspect of the excavation of 2016 in La Estación of Beniaján. On the right, the aspect of the excavation in the IES Beniaján 2015.

We wanted to question the notion of simulated excavation and archaeology as a part of or as a tool only for the teaching of history. The role of the participants is usually limited to 'discoverers' of objects and, far from trying to make them relevant to issues important to local people, discoveries are framed within contexts that are either well-known (Egypt), or very difficult to understand (prehistory), or easy to understand and attractive (Roman remains, tombs, megaliths). The main intellectual effort has been

3 Archaeo-drome. Retrieved from http://www.arqueologiaenbeniajan.blogspot.com. 4 Arqueo-IES Beniaján. Retrieved from http://www.arqueoiesbeniajan.blogspot.com. 
to "identify historical elements in objects and not to think about the archaeological methodology itself that has been done" (Mármol, Marín and Muñoz 2015). It is the discourse of material objects and their role in a historical linear chronology that stifles any attempt of dissent.

\section{0th-11th CENTURIES AD}

During the Tang and Song dynasties, China produced certain kind of ceramics coveted in the Islamic world. The Tang Dynasty (618-907 AD), which had its capital in Xi'an (Shaanxi), led one of the most prosperous periods in Chinese history in terms of trade-exporting various luxury goods to both the Islamic world and kingdoms in Korea and Japan. The Abbasids (haiyi dashi, or 'caliphs dressed in black') would face the Chinese for the control of the region of Kazakhstan, in the so-called Battle of Talas in 751 AD. The eventual Chinese defeat resulted in the permanent withdrawal of the Tang in Central Asia ( Li 2006: 47). It is at this time that China developed their commercial potential, exporting porcelains, silks, and importing spices, minerals from India and Malaysia, lapis lazuli from Central Asia, honey and wax from Scandinavia and Russia, and ivory from Africa. The camel caravans came and went carrying objects and food from Egypt (rice, millet), Syria (metals, nuts), Arabia (brocades, weapons, rubies), and Persia (silk, perfume, vegetables) (Li 2006: 47). The Chinese pottery production had come to the Middle East around the 5th century, although the logistical transport conditions had prevented regular trade at least until the arrival of the Tang in the 7th century (see Li 2006).

Chinese ceramics, which had been traditionally funerary, came with the Tang to occupy a more prominent role as tableware. The decorations that were previously dedicated to the dead now served to give value to these luxury items. Decorative materials used (enamels and white paste kaolin) were preferred by the aristocracy of the state. This was a new craze that introduced into the upper classes the regularisation of the acquisition of luxury goods, and new ceramic uses in special events, such as tea ceremonies. But the revalorisation of ceramics also involved the differentiation of the kiln for its quality and styles and specific ceramic types. High 
demand within and outside of China led to the emergence of new production centres, and pottery kilns which until then had produced funerary ceramics were forced to reconvert these into dishes. Each production centre would develop its own style, presenting a mixed picture that would intensify with the Song dynasty (960-1279 AD) from the 10th century on.

The demand for pottery increased the competitiveness between the kilns, carrying the appearance of new creative elements in lowerquality kilns, such as the one of white vases of Gongxian and the one of the green urns of Changsha. For example, in Gongxian, the former funerary artisans adapted their style to tableware, adding colours such as copper or cobalt arranged in new ways, with green splashes and blue figurative designs. Changsha kilns, meanwhile, created iron and copper tones like brown and green, and occasionally red motifs painted with glazes and enamels. The main product, porcelain, was manufactured in a series of ovens throughout the region, such as in Xingzhou (Xingtai, Hebei), Yuezhou (Shaoxing, Zhejiang), Wuzhou (Jinhua, Zhejiang), Shouzhou (County, Anhui), Yuezhou (Yueyang, Hunan), and Dingzhou (Changde, Hunan), among others (Li 2006: 66). Artistic independence obtained with the Tang would turn out to be profitable for the Song, due to the existence of ceramic models in high demand outside China (for typologies, see Wood 1999: 197; Sullivan 1999: 118). The white and blue porcelains were exported through Guangzhou to Southeast Asia, India, the Islamic world, and East Africa.

In Fustat, in the suburbs of Cairo, there appeared many fragments of Tang three-color style sancai porcelains, Xingzhou white porcelains, Yuezhou yellow and brown porcelains, Changsha porcelains, etc. In Shapur, Iran, there appeared Tang porcelains from the 9th and 10th centuries, along with artefacts from Xing, Changsha and Yuezhou kilns. In Karachi, Pakistan, porcelains from Yue kilns, a green bowl of porcelain with floral motifs and a yellowochre glaze from Changsha were found. Porcelain fragments were also found in Samarra, Iraq. On the island of Kalimantan, Yue pieces of the 9th and 10th centuries were found, and in general we can find this kind of pottery at other sites in Indonesia, Egypt and Iran that were connected with the Maritime Silk Road ( $\mathrm{Li}$ 2006: 66-67). 
86 - José A. MÁRMOL - Dropping the Trowel...

In return, the Chinese imported ivory, pearls, spices, and large quantities of medicinal materials from India, Arabia and Byzantium. Trade with the Islamic world was articulated through a number of key seaports connecting great medieval commercial centres, such as Guangzhou, Baghdad, as well as Samarra and Fustat (Zozaya 1969); through the Chinese ports of Jiaozhou, Guangzhou, Fuzhou, Quanzhou, Mingzhou, and Yangzhou; and Islamic ports of Basra, Siraf, Sohar, Alexandria, and Cairo, among others, from where objects were redistributed to other centres such as Constantinople (Li 2006: 47, 67).

It is possible that the Chinese authorities who controlled the trade did not place too much importance on ceramics to prevent their export. When China lost the monopoly of silk production, the export of fabrics and luxury products was banned (in the 8th century), resulting in a larger field developing to achieve an absolute monopoly over ceramics. In fact, its main competitors did not have kaolin, the clay necessary for the creation of materials such as porcelain, nor had they the creative and technical resources to produce Chinese decorations, especially sancai, which is characteristic of the Tang dynasty.

The ceramic heterogeneity that existed in the Islamic world was the result of experimentation in forms and techniques, not only with in-demand glazed ceramics, but also with storage pottery. It is curious that among all the Arabic terms that refer to ceramic, only sini refers exclusively to fine glazed ceramics, with sini coming from the Arabic term for China, al-Sin (Meri 2005: 143-144).

One of the original inventions of Islamic potters was golden earthenware. Iraqi potters appear to have been the first to experiment with this type of decoration with opaque glaze in the 9th century. Pigments, oxides of silver and copper, vegetal motifs and figures, and firing under certain conditions resulted into ceramics which looked like gold or silver, which was a great success throughout the Islamic world, as well as in India and Thailand. This technique would come to Egypt in the 10th century, with the migration of Iraqi people to the Egyptian Fatimid caliphate (see Meri 2005). 


\section{0th CENTURY AD}

In Dropping a Han Dynasty Urn (1995) the artist staged the act of throwing a Han dynasty urn down. In this series of photographs, the artist is seen without any facial expression, as if the value of the urn had nothing to do with a cultural or historical perspective. The ultimate goal of this performance of the artist destroying the object is to photograph it. For that reason, the artwork becomes a piece of conceptual art. Still, the act of dropping an ancient urn, while destroying 2,000 years of tradition, culture and history, has to do with the role played by this destruction into the redefinition of art and culture. The status of the object (its coherence, limits, etc.) is changed by new ideas and values, anthropological and social, which emerge through art.

\section{1st CENTURY AD}

The creation of a simulated site (in our case, in Murcia) goes through several processes of conceptual definition, since it must be a didactic and aesthetically appealing space for dissemination. The first step was to view, in a conceptual manner, how it would become a site and what technical and chronological limits it should have. Attending to local cultures and sites, as well as the issues towards which we wanted to contribute (integration, poverty, marginalisation, identity), we divided the site into three levels, corresponding to the contemporary age (20th century), the medieval age (Islamic and Christian stratigraphic levels), and the Bronze Age. Elements of local sites were included to raise awareness of their protection, and to give the feel of a real site, which later gave us data on post-depositional processes. About the space: one of the sites was $5 \times 3 \times 1 \mathrm{~m}$ and another $5 \times 5 \times 1.5 \mathrm{~m}$, where the three levels of earth would be shown, slightly different in colour and texture.

The excavation worked by dividing the participants into two teams: excavation and laboratory. The first would excavate the site using grids, and the second would have to analyse all data received. Leaving didactics aside, the advantage of this experience was that it allowed us to feel like archaeologists again, after a long 
hiatus of not participating in projects or interventions due to the current state of the archaeology sector in Spain. We were able to think and reflect on not only archaeological data, but above all, and since the data were built on false materials, the methodology and the social aspects of discourse, the role of archaeology in the resolution of conflicts, as well as new forms of seeing archaeology in line with public and local interests.

To reflect on this, we used audiovisual documents produced during the courses. Through filming the actors during the excavation, we could explore how interpersonal relationships were formed, what kind of vocabulary and meanings were employed by the participants, how knowledge and interpretations were created, etc. In a broader sense, we were carrying out a sort of archaeological ethnography (Edgeworth 2003, 2010).

\section{0th-11th CENTURIES AD}

But the taifa are very unstable political units, despite their strong economic activity. Their instability had little to do with the development of a creative and artisanal Western Islamic world, and imitation productions (in this case, of ceramics) springing up in the East and East Asia.

We have examples of these relationships in the materiality. Significantly, 11th century ceramics decorated with cuerda seca (dry rope), appeared during this period in North African sitesespecially in the old excavations in Fustat, offering evidence of an active trade from Al-Andalus. Imports are also found in a few cases in Badajoz and Almería (Valdés 1991: 324). For example, in the citadel of Badajoz, an Eastern object appeared, possibly Egyptian: a pipe of hashish, glazed blank, made on a reused plate fragment, a material far removed from the technical possibilities of the Andalusian potteries of the time, and impossible to manufacture in the peninsula until the 12 th century. Along with the pipe, a piece of cut glass with vegetal motif decorations also appeared (Valdés 1991, 1995). 
In 1969, the archaeologist Juan Zozaya was digging in the Islamic alcazaba (citadel) of Almería when he found four pieces of Chinese porcelain, according to his interpretation (Zozaya 1969: 192; this interpretation is not without controversy, see Whitehouse 1972: 69-70) (some in Figure 3). The fragments are:

1. Part of an edge of a bowl, of $10.7 \mathrm{~cm}$ in diameter, with white paste and translucent glaze. The exterior is decorated with lotus leaves in relief. Inside, it has an Arabic inscription in green, painted under the glaze. It contains a Koranic inscription 'Almulk lilliihi' ('Power belongs to God'). The kiif character in the word mulk is not correct, something which led Zozaya to think that it was made by a Chinese craftsman who was not familiar with Arabic writing (Whitehouse 1972: 69).

2. Piece of the base of a bowl of $8 \mathrm{~cm}$ in diameter, glazed and with pastes like the fragment. The decoration consists of a series of arcs and circles with a possible motif at the centre.

3. Piece of an edge of a bowl, with white pastes and translucent glaze.

4. Piece of an edge of a bowl of $8.5 \mathrm{~cm}$ in diameter. Poorer quality than the previous ones, made with opaque pastes and a translucent glaze.

Zozaya considered that the fragments 1, 2 and 3 contained kaolin. However, the presence of white and translucent pastes opens up the possibility of these being not Chinese but Persian productions (Whitehouse 1972: 69). They could, in fact, be Islamic imitations of Chinese ceramics, which was something common in Persia at the time. Moreover, the Arabic inscriptions have no analogies in Chinese ceramics. Therefore, the specific origin of these fragments would have to be considered with caution. The fact that they are imitations of Chinese porcelains and appearing in Almería is another matter.

Chinese ceramics from the 9th and 10th centuries contained inscriptions: the character ying (stock) appears in several glazed bowls, and jinfeng (tribute) on a white plate. Both pieces are from Gongxian kilns. However, inscriptions were not supervised; smaller workshops especially copied inscriptions for the 'open' market and 
not for the court. The inscription guan (official) has been found in ceramics from the 10th to 12 th centuries, including temples and tombs (contexts of certain social importance), while it also appears in smaller, similar productions for decades, such as those found in the Belitung shipwreck.
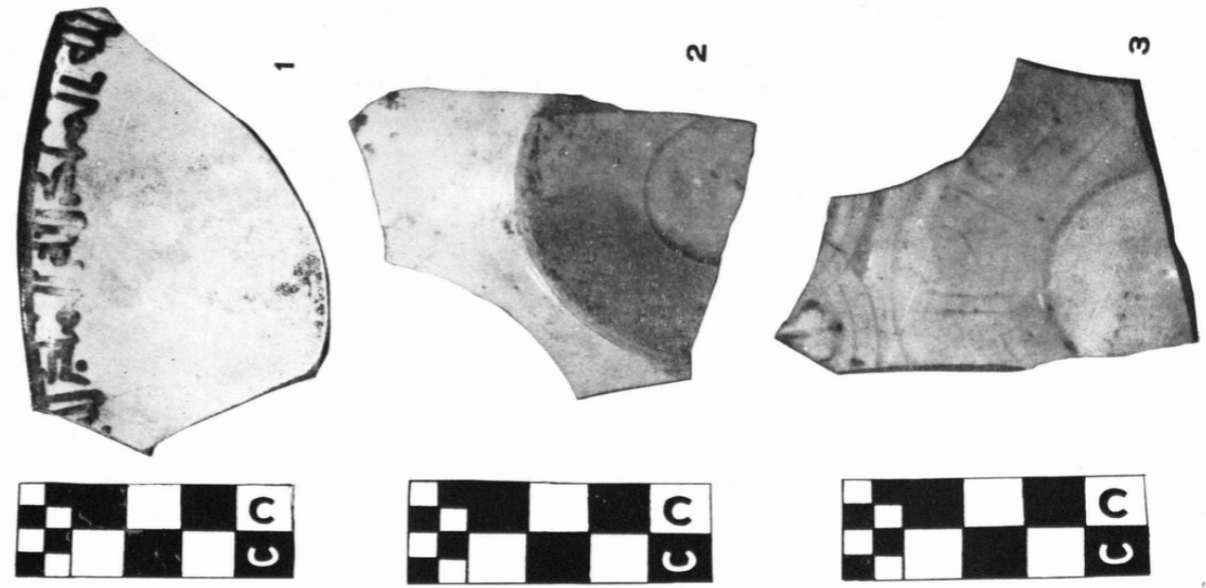

Figure 3. Fragments ( 1 and 2 ) found in the Islamic citadel of Almería. Zozaya 1969.

Fragment 1 must have had a pigment that had to be gold (Valdés 1995: 167). It is dated from the 10th century, and the inscription could demonstrate its eventual destination, the Islamic world, from East Asia. Fragment 2 is decorated with incised decorationseemingly indicating that it belonged to a Ying $\mathrm{Ch}^{\prime}$ ing, who imported it to Egypt in the late 11 th or early 12 th century-that has served to date all the pieces (Valdés 1991: 325, 1995: 170; Zozaya 1969: 195-199). They have been classified as tableware of the Song era, dated through comparison with other fragments of golden earthenware from the period of Abdul al-Rahman III (10th century) - a time of extensive development of Almería's seaport, which grew during the taifa kingdoms until its conquest in the 12th century (Valdés 1991: 325). These 'exotic' products have come from an intermediate point between China and Al-Andalus, namely, Fustat. 
José A. MÁRMOL - Droping the Trowel... - 91

\section{0th CENTURY AD}

The meaning of the objects is the key in this process of destruction, because what Ai Weiwei does with the Han urn could well be considered both a destruction of heritage as well as the creation of something new. Mao's China had tried to obliterate, willingly or not, all traces of the traditional rural culture of China. Ai considered that archaeological vessels may be prefabricated art works, which he could enhance by making them relevant to what happened with Chinese heritage. But his works also question what we value: It is not confirmed that the destroyed urns were real archaeological artefacts. The counterfeit Chinese pieces had reached such a level that there is no way to identify the true from the false, because the techniques to make one and the other were the same, both in the 20th century as in the Han Dynasty era (Cohen 2015).

This conceptual work reached its zenith when the Han Dynasty Urn with Coca-Cola Logo was bought by the Swiss ex-ambassador in Beijing, Uli Sigg, one of the biggest collectors of Chinese art. The work became the most prominent contemporary Chinese art icon, a universal metaphor representing the clash between consumerist progress and the preservation of historical artefacts. Inspired by Dropping a Han Dynasty Urn (Figure 3), the Swiss artist Manuel Salvisberg created a photographic triptych called Fragments of History (2012), in which we can see Sigg in an almost identical position to that of $\mathrm{Ai}$. On this occasion, the collector dropped the Coca-Cola logo urn, which had been the highlight of his collection, destroying it in pursuit of the creation of an artistic work referring to the tradition of appropriation and iconoclasm of Ai. This work reflected the issue of the 'moral rights' of artists in relation to acts of appropriation of their works, which is of course nothing new, as the concept had already appeared in French law since the 18th century and in Chinese law since the early 20th (Yap 2012).

Ai's artworks of the destruction of antiquities were harshly criticised in the 1990s, being termed as acts of vandalism against cultural antiquities which could be worth thousands of dollars (ibid.). Similarly, the artistic work that emerged from this act has become one of the great works of contemporary art, with its 
92 - José A. MÁRMOL - Dropping the Trowel...

economic value possibly exceeding the economic value of the Han urns, posing great contradictions in public policies on the value of heritage.

\section{0th-11th CENTURIES AD}

In the process of experimentation and imitation, Islamic potters discovered new decorative techniques as those found in Samarra and Basra (9th century), linking the use of cobalt blue pigments and opaque white pastes (Meri 2005: 143-44). Iraqi potters had a monopoly on cobalt blue until the appearance of stoneware in the 15th century, when cobalt was exported to China. The Chinese white and blue ceramics arrived in the Middle East (reinterpreted by the Chinese), and are highly sought after in the Islamic commercial world, in which we see again imitation processes, including purely Chinese motifs. These ceramics are the direct antecedent of common ceramics of the modern age in Western Europe (for example, the Valencian Manises style).

The influence of Chinese ceramics on Islamic pottery is strong and elongated in time, from the 9th to the 19th centuries. However, the Arab potters sought above all imitation of whiteness and elegant and slender forms of Chinese porcelains, without the necessary technical developments (kilns capable of reaching high temperatures for glazes and kaolin clay, the basis of Chinese pottery). Nevertheless, in their efforts to imitate porcelain, ceramic potters developed some alternatives composed of clays with a lot of quartz, to add hardness and white tones to the productions. This pottery, called stoneware, would be used by the Islamic world from the 12th century to the acquisition of kaolin clay in the 18th century (Meri 2005: 143-44).

\section{1st CENTURY AD}

The managing of expectations had positive results among the team, especially with the significant dissemination of the activity, key to explaining the importance of heritage as an inseparable part of the characteristics and experiences of the participants' local 
living spaces (see Ham 1992). The main idea was that the students learned archaeology and developed a critical consciousness to value and protect the local heritage. The learning by discovery would be combined with the perception of the importance of the remains as part of the daily lives of the students (Mármol, Marín and Muñoz 2015). They used what we transmitted, and adapted it to their own speech through acts of collaborative knowledge (Scolari 2013: 24), without repeating it. This became evident at the end of the activities, when students had not only created a series of microdiscourses around the site, but also adapted it when communicating this information to their families, teachers, and other studentsbeing prosumers, i.e. producers and consumers at the same time of their own knowledge (Scolari 2013: 27).

All this, coupled with the fact that the simulated excavation is primarily a form of training for archaeologists, made us understand that what matters in these cases is to generate emotions, as it is decisive when observing what elements of archaeology are more interesting for students. The emotions reinforce the links between what is unknown, the archaeological, and other members of the team, with their peculiarities and differences, becoming relevant aspects of everyday life (Mármol, Marín and Muñoz 2015).

\section{PRESENT}

What the child has seen just by looking at a medieval urn atop the table-laboratory of the excavation of the site in his town is a way of looking at the archaeological, where disciplines, times, materials, experiences and reflections intermingle.

\section{The 'treasure' of archaeology}

The appearance of several temporary lines in a space designed to tell only one story (the right), forces us to think not of a single discourse that paints a clear picture, but several discourses depicting different images, that together represent the three levels that I want to address in this study: the archaeological, the public/educational, 
and the creative. Each of these levels has its own problems and related discussions, but all three can appear simultaneously in our contacts with materiality. In addition, I have proposed three spaces that are mainly visual, although each is worked and visually thought through the relationship between concepts and visuals to become material actions.

Images are representations of reality, which also involves the use of a narrative sense for the content, the creator, and the viewer. It is possible that one of these elements produces a narrative that predominates over the other, as happens with the image of archaeology. It is not a new idea that, because of film and media, the image of archaeology has been based on a mix of archetypesadventure, colonialism, esotericism, and romanticism-and the figure of the archaeologist has carried the image that first arose with the adventurers of the 19th century (like Max Mallowan Hiram Bingham, Leonard Woolley, or Otto Rahn) and has not changed in essence (Figure 4).
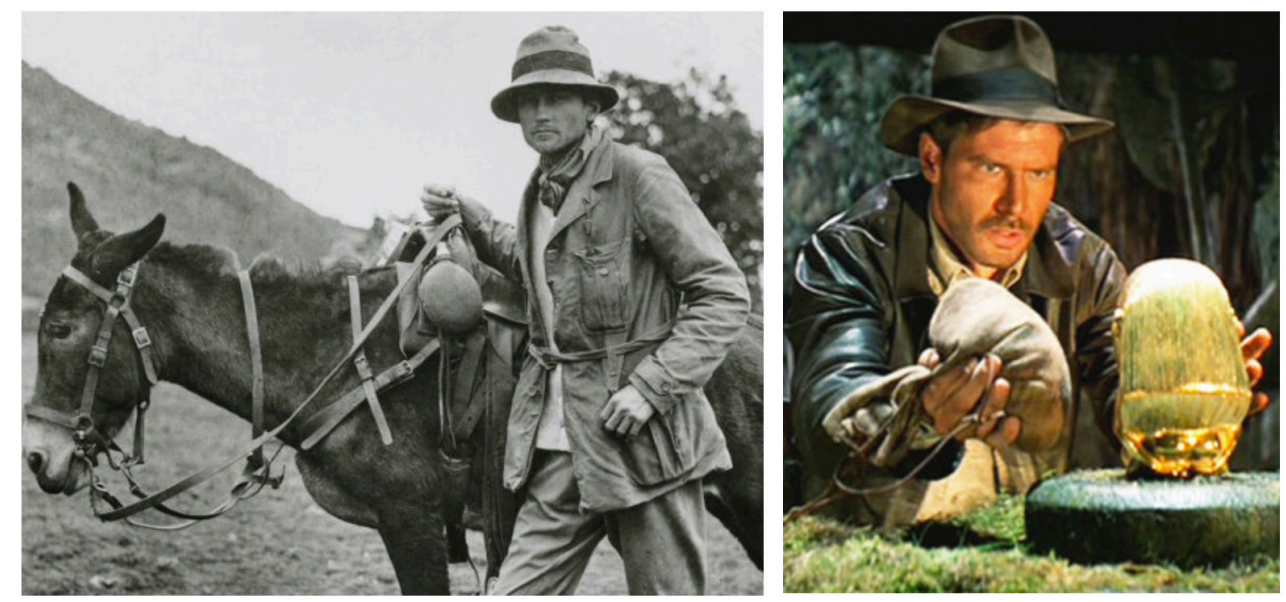

Figure 4. On the left: Hiram Bingham. On the right: Indiana Jones. The archetypical image of the archaeologist.

In fact, archaeology is depicted as being more than a practice or a concept; it is a lifestyle that is barely compatible with the sedentary, 'civilised' lifestyle of our Western cities. Ideas like discovery and ancient set a temporary boundary that can nullify the 
role of the archaeological to solve the conflicts of the present. The memory of old things is also ignored, in favour of the spectacular and the peculiar; and once they are studied, these old things end up in museums, where they die (Millán Pascual 2015: 52). If this serves to fight unfair present situations, it is something that the public is hardly going to notice.

In this situation, it seems that we should be creative when we use, "see," or "feel" archaeology (Hamilakis 2015), because to rescue the memory of the materiality we use ways of thinking closer to art than history, with a difference in the range of action: with art we can recover spaces, represent local people and their problems, and create new experiences in spaces that become multitemporal, authentic new-archaeological sites, especially when art is practiced outside the museum. Taking the common space, the street, art is superimposed on everyday life flows as an ephemeral critique of injustices, inviting the viewer, who understands street painting as a heterodox act, to reflect on them. The common space is transformed into a space of rebellion, where the presence of an artistic work whispers new convictions to all citizens. Should not the same happen when archaeologists get involved in areas historically constructed as sites?

It seems that archaeologists always fall into the discourse of objectification, which transforms everything that once contained memory into consumer goods. The artefacts of the past have been considered 'antiquities', 'national treasures' or, more recently, 'vintage' (Millán Pascual 2015: 62, 64). In this respect, art and archaeology share a destination: the nullification of the reflections that material provokes. Otherwise, our actions would be closer to activism than to the academic.

Archaeology does not provide us data from a dead past, but from an active present where things that are not anymore can be activated to make us reflect on our convictions. Convictions that have to do with the perception of the world, the production of knowledge, the perception of materiality, the temporal, memory, and the aesthetics of the conventional. With artistic practice we aims to revive this perspective and to position archaeology as a starting point to act as a solution to the problems of the present, caused by terrorist phenomena, and contribute to the process 
of social cohesion, integration, multiculturalism, and resilience. Our standpoint is in the present society and not in the past, because, after all, the present is the place from which we look at the past. This claim has been made by a number of theorists and practitioners from the fields of public archaeology (Almansa 2014; Merriman 2004), the archaeology of the senses (Hamilakis 2014), archaeological ethnographies (Edgeworth 2003), or the creative archaeologies in general.

It is for these reasons that I believe that archaeology is purely visual. It builds with images, and rebuilds the past through representations of visual imagination, as Stephanie Moser (1998) argues. Following this author, to think archaeologically is a way to think visually: all the work done in archaeology can be condensed into images in different formats and media. Archaeology is not only dedicated to the investigation of an archaeological view of the remains of the past, but the record itself is a visual metaphor (Ruiz Zapatero 2014). We investigate with photos, drawings, ideas and imagination. It is a process related to the visual, from putting a hypothesis into practice and conceptualizing the work and its development, to reaching results and reconstruction through imagination. But there is also a visuality that concerns how others perceive us, which determines some of our methods and procedures.

The position of archaeology in the actual world, in terms of a position within the flow of human activity, has come about due to the close relationship between archaeology and actual culture (González 2011; Mármol 2014). The spread of stereotypes about the figure of the archaeologist has been partly inevitable, since it represents a great attraction-it has archaeo-appeal, the "magic of feeling Archaeology" romantically (Holtorf 2005: 156). This, through everyday experience, reflects the value of archaeology for the public thanks to the influence of the media.

But access to a more realistic image of archaeology is still a challenge due to the different types of existing dissemination. While "high dissemination" (Comendador 2013: 115-135), created by official organizations is produced by media using a more accessible language and therefore much more popular, but with questionable contents. The interest of the public in real archaeology is diluted due to the impossibility of a horizontal dialogue between the 
official and the popular. This problem of vertical dissemination also occurs with the participation of stakeholders in the research, avoiding their participation in the construction of the academic knowledge (Castañeda et al. 2008: 2). In addition, we face not only the consequences of the fact that the labour of archaeologists is unknown, but also administrative marginalization (Ruiz Zapatero 1998; see Almansa 2014).

The practice of archaeology can be seen as a marriage of actuality, the community, and the perspectives of the past and present. As an instrument of resilience, archaeology needs to be honest with its projected image. If what it projects does not correspond to observable reality, a feeling of disappointment occurs (Tejerizo 2011: 393), which locks us in the literary artefacts that we produce. This usually occurs because 'real' archaeology is not present in daily life, and therefore does not emerge in the political, public or economic fields of public interest (Carvajal, Hernando, De los Reyes 2011: 39-48). Academic demands, which often involve great efforts to study topics of questionable relevance, limit our 'activism', exacerbating the discrepancy between our intentions and disseminated images, along with the difficulties to perform collaborative actions between archaeologists.

The space where the past connects to the present through archaeological practice, i.e., the sites, do not help the 'visibility' of archaeology when compared to monumental sites that receive greater publicity, neither for the public nor for the specialists (Ruiz Zapatero 1998). The need to make inconspicuous sites understandable through great historical discourse hinders reflection on the particularities and unique nature of archaeological remains, visible through an image composed by different sites and imagined environments. At this point, we can introduce visual reflections. Many practitioners of land art have reflected on the dialogue that we can generate between us and our culture with natural space. The question is: can we consider archaeological practice in a specific site as a work of land art? Urban art is another practice directly involved in living spaces, opening up the possibility of dialogue, not between us and the space, but between our time (from which we look) and others (when the work was created, the content of the work, etc.). 
98 - José A. MÁRMOL - Dropping the Trowel...

The archaeologist who is responsible for 'saving' the 'progress' from the evil represented in militarism, radicalism, terrorism, etc., acts on a past that is a metaphorical representation of the fears of the contemporary world. We place our present problems and hopes in these historic spaces of the past, in search of analogies and possible solutions (from the past) or for future reflections (in the present) (Molina 2008; Rosenstone 1997). However, it is a distant space, which is not. So, maybe we should move the imagined space of the past to a space of the present, based not so much on thinking the object but also feeling the experience (see Hamilakis 2015).

\section{The 'archaeological' 'Art': Virtual borders in the vision of archaeology}

The creation of visual artefacts allows us to capture fleeting moments in time, full of sensibilities. In this effort, we found two factors: the eye of the agent that creates, against what is represented; a 'built gaze' of the reality that is registered, in front of the "sensuousness that is captured", and therefore the sensorialities it causes. It is not something new within archaeology; photography has been used to "think with eyes and hands" and "evoke textures, smells, tastes and sounds" (Ruiz Zapatero 2014: 65) in a multisensory and phenomenological experience.

Archaeological photography consists of the creation of artefacts, photographs, videos, drawings, reconstructions, etc., that enclose the subject of the archaeological study, that is, the memory (see Olivier 2008; Ruiz Zapatero 2014: 56). Photography is born out of different moments at the crossroads of materiality and corporeality, such as the delimitation of a space in the camera, the choice of the space, and the act of shooting (Ruiz Zapatero 2014: 56), and transforms pure material objects into artefacts that evoke sensitivities experienced in the reality represented. This does not unleash all of its significant potential (Hamilakis et al. 2009: 286), or directly lie in its intention of transparency (Van Dyke 2006: 370,372 ). In fact, the aural capacity of the audiovisual has in itself a very powerful evocative capacity (belles noiseuses), which 
emphasises the losses that occur by reducing the given experience into a single visual artefact (Witmore 2006: 273-276).

The visual challenges the real, and shows in its materiality a process of bodily and subjective perception for both the observable and the observer. This is a qualitative advantage for the visual compared to writing, while influencing much more the viewer through presenting a version of the intentional reality through a "strategy of representation" with persuasive power (Ruiz Zapatero 2014: 56; Van Dyke 2006: 370). The succession of images and its aural sense offers a greater sense of being in a place that facilitates the mediation between the body and the space (see Widmore 2006).

The pictures act as interlocutors in the process of telling stories of the past and articulate them. They connect us with another time, as do the archaeological finds, and allow us to build relationships with an absent past (Shanks \& Svabo 2013: 97, from Ruiz Zapatero 2014: 59; translation mine).

The visual representation connects both the real and the bodily, reconciling the unreal and the real, through the studium, the set of codes that give meaning to the image, and the punctum, the sentimental elements that produce the meanings (Van Dyke 2006: 372). Through artistic practice, with the juxtaposition of images and other visual and aural documentation, we can recreate a hypermedia experience that allows us to question our usual interpretations and to invent and recognise new meanings (Webmoor 2005).

With the archaeological imagination, as a creative exercise, we can "imagine, represent scenarios and processes that allow to understand what has stayed from the past, the material remains, from their disappeared living contexts" (Shanks 2012, from Ruiz Zapatero 2014: 67; translation mine), leaving the textual as a form of expression that depends on the overall ability of the researcher to offer an interesting speech (Ruiz Zapatero 2015: 18) unlike the visual and its potential beyond the iconic. 
Visual artefacts are also "immutable mobiles" (Van Dyke 2006: 370, 372; following Latour), which can be moving without losing its meanings as artefacts. Indeed, this immutability allows the creation of new meanings and interpretations. In this visuality, occurs the same as in any archaeological site: it gives rise to a moment of the past which has a clear calling for the future, and therefore is a testimony of human acts that can be imitated (aesthetically at least) over a time almost infinite. The important thing of these objects is not its materiality but the universe they represent, which goes further by applying metaphysic and unstructured concepts of reality. These metaphysical concepts have their own reality-as occurs in the poetry-reflection of Stephane Mallarmè. In his poetry, words like verbal units are of secondary importance, because what matters is the fullness of what they evoke, forming relationships of meanings to the materiality of the written poem, but without grammatical relation. In Mallarmè, a hand-held fan is not only a fan, but also the air or the sound it makes, the effort of the craftsman who made it, the movements of the lady who holds it, or the decay as a concept of absolute decay when the fan sways in the sunset (Friedrich 1959).

Following the example of other works like "The Golden Marshalltown" (Flannery 1982) or "Three Rooms" (Shanks 2004), this work intentionally includes of the parallel presence of several actors, perspectives and times, with differentiators that establish a dialogue between them, and enable the reader to interpret alternative acts and facts of the past and human experiences in concrete sites. In the case of "Three Rooms," the sense that Shanks gives is presentist, since its objective is to create a transversal interpretative line that activates a way to conduct archaeology for the present, or at least to develop other ways to feel the site as a whole. In an attempt to imitate his work, at the beginning of this paper I have proposed three important moments (the analysis of material artifacts, the artwork of Ai Weiwei inspired on archaeological ceramics, and the simulated excavation as a social, educative event) for a creative vision of archaeology. I think it helps us reflect on the role of archaeology in the processes of social and artistic signification. 
These perspectives build a visual imagination that comprises a universe of things that are not seen, but are-that is, subjective and dependent on personal conditions. Something like what Karl Heider called the "Rashômon effect" (Heider 1988) when discussing why anthropologists disagreed on subjective issues. Heider created the term, of course, based on Akira Kurosawa's homonymous film (1957), famous for its fourfold narrative where there is no real truth but four interpretations of the same moment.

The possibility of using this type of visualities adds an element of mystery, a void of meaning in which new and original relationships by the viewers are formed. Confronting this mystery is relevant, making an image a powerful tool in the collaboration between people to confront contemporary fears.

A way of integrating the creative into the archaeological could be, from archaeology, artistic-ethnographic photography (Hamilakis et al. 2009: 291-293; Ruiz Zapatero 2014: 66), developed to document the technical and human processes given in archaeological projects for the inclusion of local communities. From here, we could change the direction of the image we project of archaeology, from the anachronistic to the current, and from the romantic to the relevant. From the field of art, considering those works that have to do with materiality and temporality, such as Dropping a Han Dynasty Urn (1995), which also has a relation with performance (whose contacts with archaeology have been fruitful, see Shanks and Pearson 2001; Shanks 2004; and Hamilakis et al. 2001 and 2009), Han Dynasty Urn with Coca-Cola Logo (1994), or Sunflower Seeds (2010) by Ai; the works of encapsulated trash by Arman; Phallusies (2010) by Simón Fujiwara; and other urban artworks by artists such as Banksy, and Land Art such as Cadillac Ranch (1974) by the group Ant Farm, or Intervention Reforming VII Las Palmas (2009) by Eberhard Bosslet. We also find interesting reflections from illustration, in artists like Eneko, and in photojournalism, the most prominent being the series of photographs of the objects of the Syrian refugees in Greece in 2015 by Santi Palacios ${ }^{5}$.

5 Materiality of the Syrian refugees in Lesbos by Santi Palacios. Retrieved from: http://www.huffingtonpost.com/entry/photos-objects-migrants-left-behind us 56210c50e4b08d94253ec656 
From the field of archaeology, we find works by archaeologists, such as Jean-Paul Demoule ${ }^{6}$, that mix art with photographs of archaeological excavations, or Daniel Spoerri who celebrated a banquet in 1970 by burying it whole in order to excavate it in the future. ${ }^{7}$ In a more intermediate sense, the Kyoto Art \& Archaeology Forum promotes dialogue with archaeologists and artists by creating encounters between them in museums and sites.

If archaeology is about the "social materiality of the Past" (Ruiz Zapatero 2014: 66), it would also take care of the social materiality that provokes the past in the present. When the past is perceived from the border of the present, some identities which legitimise certain communities to build their reality in a given space are configured; it is a permeable border. To be aware of how our convictions about the past have been produced, it is essential to know how we build the knowledge as archaeologists, helping us to reveal social relations in the process (Edgeworth 2010: 54; more in Flannery 1984). Nevertheless, we must revise our imageheterogeneous, confused, full of stereotypes. It is proposed, therefore, to use a creative attitude which by definition would face problem solving in an efficient manner.

A case in this regard is the propagandistic use of Syrian and Iraqi heritage by Daesh, not just with clandestine excavations (in Palmyra, for example), but with the symbolic destruction of everything that is reminiscent of the control of the West in their areas of domain (besides the mass murder and destruction in Palmyra, the first thing Daesh did when it conquered the border areas of Syria and Iraq was to destroy the border of the SykesPicot Agreement of 1916, through which France and the United Kingdom shared the ruins of the Ottoman Empire and its areas of influence in the Middle East) (Figure 5). It is, in essence, the wilful destruction of 'universal' convictions, such as 'world', 'universal', 'human' heritage, or even 'human' rights, which are purely Western concepts.

6 Jean-Paul Demoule. Retrieved from www.jeanpauldemoule.com.

7 Banquets. (N.d.). Daniel Spoerri. Retrieved from http://www.danielspoerri.org/ web_daniel/englisch_ds/werk_einzel/19_bankette.htm. 

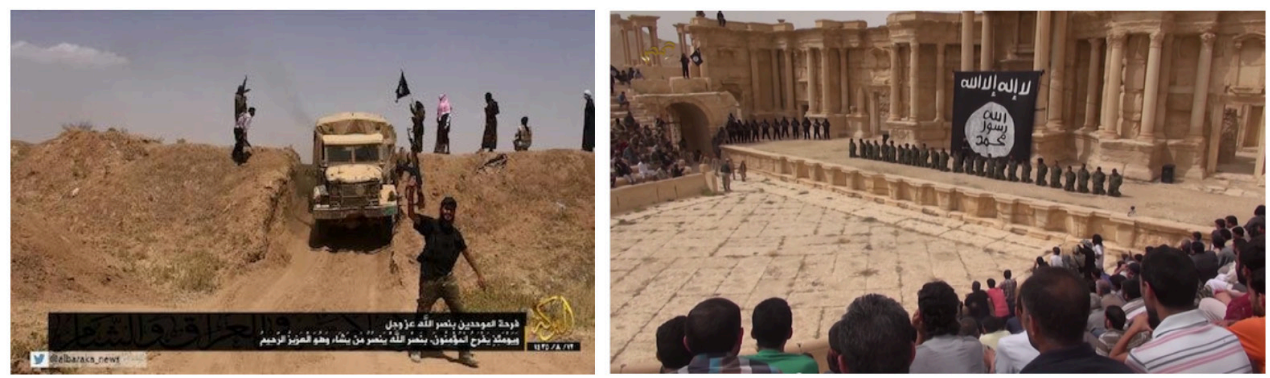

Figure 5. On the left: Daesh destroying the Spykes-Pikot border between Syria and Iraq. On the right: Daesh performing a multiple murder in the Palmyra's roman theater.

This terrorist 'archaeocide' has served to highlight something we already know: that heritage is important. And it seems that the reflections about this have not entered into the ethical and human issues that have shaped the problem (see Hamilakis 2009 on the 2003 Iraq war). To Daesh, heritage has value as it is a symbol of what comes from the past, which reaffirms some identities over others. Therein lies the potential difference of archaeology and respect to other sciences, making us question the limits that we have in the socialization of our work as archaeologists.

\subsection{In practice}

At the beginning of this study, I proposed three discourses. The first is dedicated to the strictly archaeological: a general overview of the ceramics of possible Chinese origin in al-Andalus, from the trade of the Islamic world with East Asia. The fact, for example, that the Chinese world is the place from which some Spanish ceramic innovations originates, goes against the contemporary idea of the modern expansion of Chinese shops and bazaars. The second discourse is about the contemporary use of Chinese ceramics as criticism of the People's Republic of China, and in general about the contemporary use of the archaeological for other artistic or political purposes. The third discourse discusses the didactics of archaeology in a Spanish region. To teach what we try to do through archaeological practice and enable ways to create community 
around the sites, in addition to free forms of expression, are ways to explore a more social role of archaeology and the elimination of borders in human relations.

The artistic work we obtained with the ethnographic documents that we tried to build in the didactic courses summarise the archaeological work in two actions: the performance and visual creation (for more, see Hamilakis et al. 2001, 2009; Shanks 2004, 2012; Shanks et al. 2001, 2013; Van Dyke 2006; Weebmor 2005; Witmore 2004, 2006; Tilley et al. 2000). A performance is an avant-garde show in which several elements of art from various fields, such as music, dance, theatre, and visual arts, are combined. The archaeological work was staged as a performance, in the artistic sense, while we followed a series of procedures that reproduced the archaeological methodology-in turn creating documentary, textual and visual artefacts as well as ethnographic and artistic ones.

The first work was the excavation itself. On the simulated site the students were organised as a team to intervene in the site. In the team's formation process, they adopted roles so as to interact with their classmates. The personal attitude of each student was complemented by the one of the rest, and it configured the way the team worked. Another team was located outside the site and was dedicated to the documentation and drawing, visiting occasionally the perimeter of the excavation and creating a border between the acts of discovery (natural) and the acts of inscription (cultural) (following the dichotomy proposed by Edgeworth 2003) with their body movements.

The excavation activity, with the comings and goings, the soil extraction, the discovery of objects and its documentation, the textual or audiovisual diary, and the taking of pictures entailed the creation of metaphysical spaces within the materiality of the site. The lines marking by the grid, the limits and boundaries of the site and the fact of having a team of documentation 'out' of those limits are also significant elements. These meanings were included among the experiences of the excavation and in the marginal space once the archaeological work ended. 
The second series of visual artefacts are not personal experiences, such as in terms of performance, but photos and videos in relation to the ethnographic. They show both the diversity of participants and the collective and collaborative works that are ascribed to the meanings of the site's space, as infinite testimonies of the transformation of the past in a commonplace in the present. It is in this present that the integration of all the efforts occurs. Thus, the archaeological practice reactivates the memory of a people who have so much and so little to do with us. A starting point would be to think in analogue processes given in the past and in the present, as the discourse of the Chinese ceramics being imported into alAndalus during the Middle Ages.
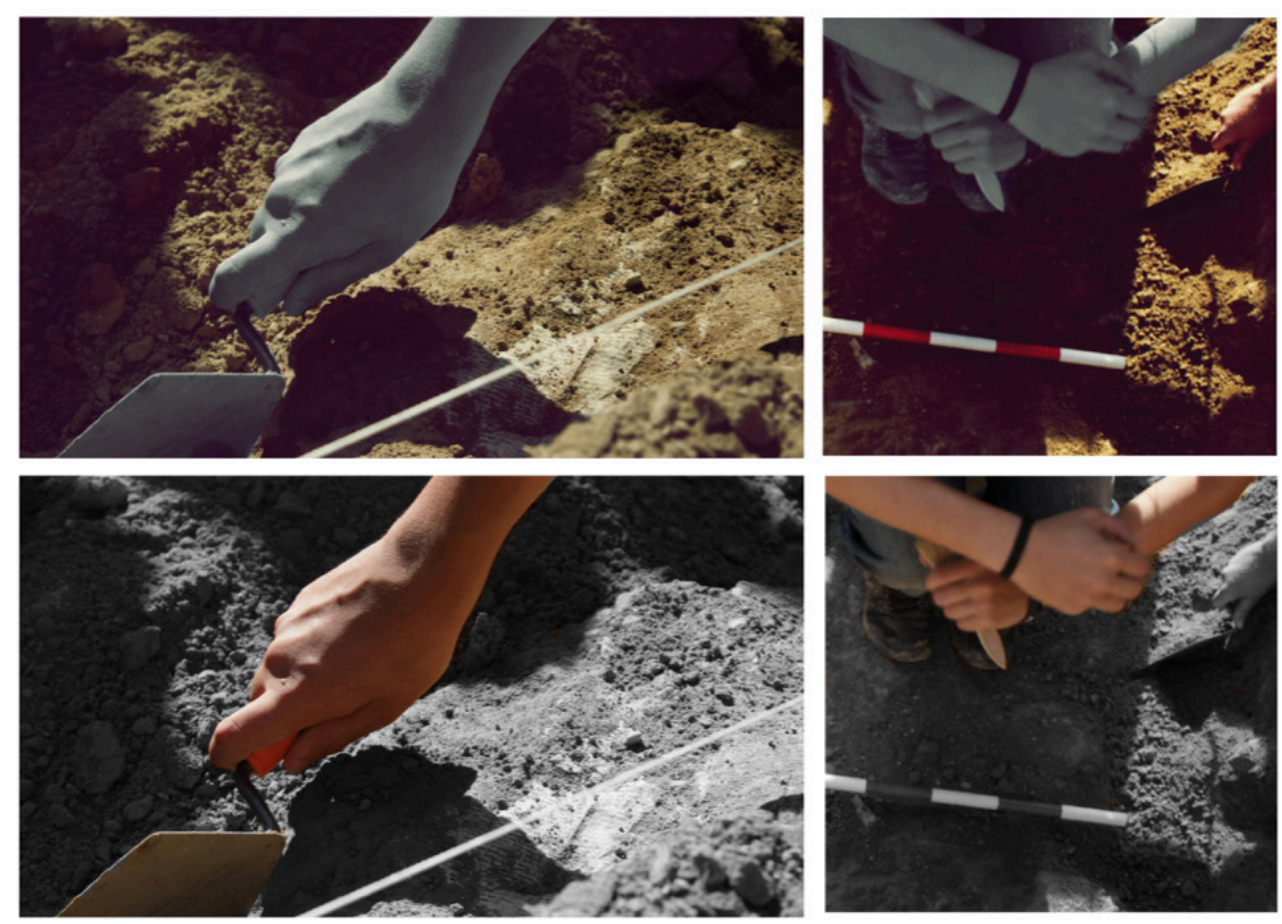

Figure 6. "The sublime preeeminence of the theoretically oriented" (C) This photographic work reflect about the role of archaeological theory in the practice, and its aesthetic. 
Reflective qualities of the visual with works of artistic content were explored to understand that some 'archaeological' pictures are in line with the production of art that deals with the basics of archaeology. In these, we can see mysteries that concern the theoretical thanks to visual metaphors that enable the capacity of imagining academically what is artistically shown. Some artistic activities we did, like drawing or sculpting, were immortalised in photographs despite their ephemerality, keeping some sensory experiences given at the site, and hardly registrable with words. The artistic material also served as mediator between the past (past reality, and the current past of the site) and present (archaeological practice and temporary present), through influencing a metaphorical mystery that contributes to generate interest in what happened at the site, and what is already witnessed in the experience of the students and their perception of what has been done. This sheds light on the importance of archaeological activity in the local community, and enables spaces of contribution to the protection of heritage in addition to reflection on the approaches to social convictions which derives from their qualities (Figures 6, 78 and 9).

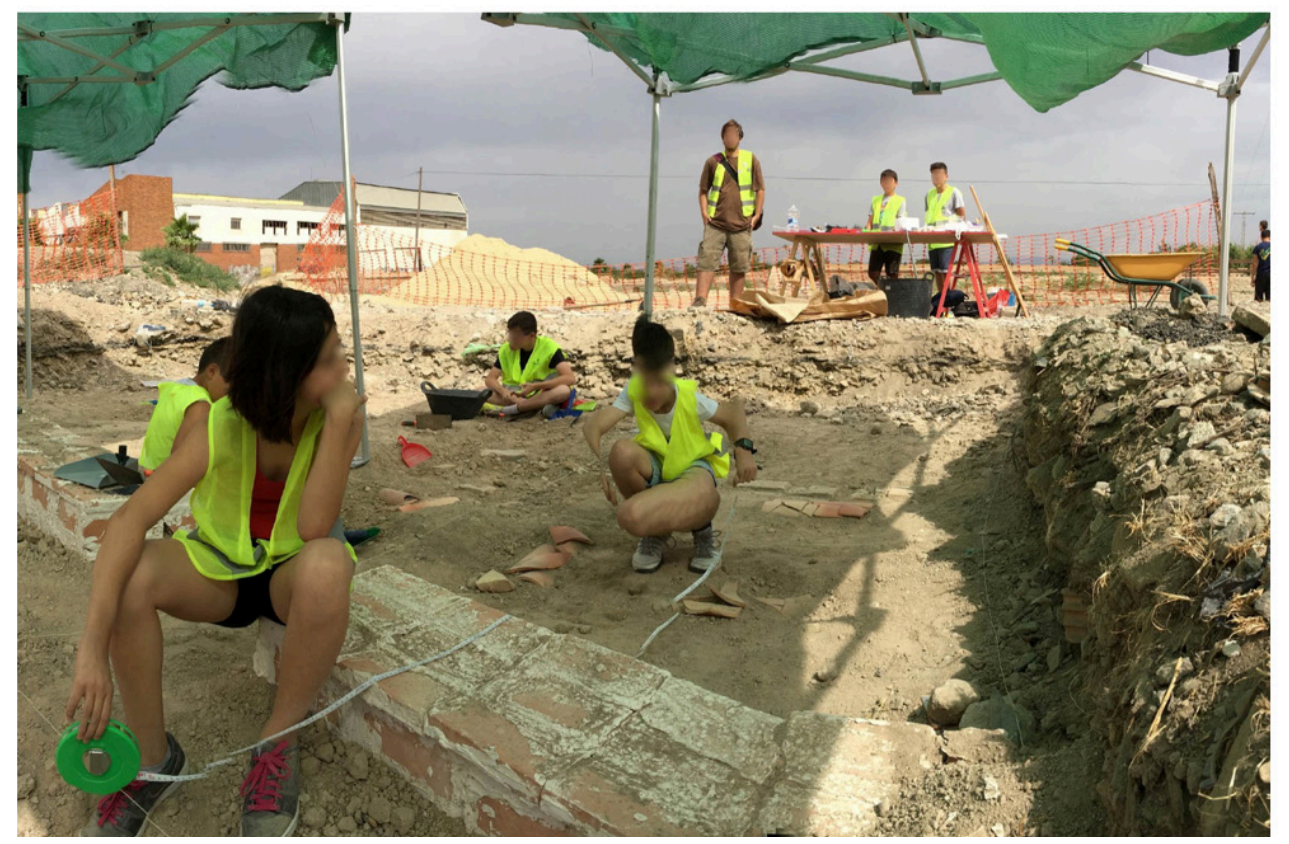

Figure 7. Frame of the performance that shows the aesthetics and hierarchies in the Archaeo-drome (July 2016) 


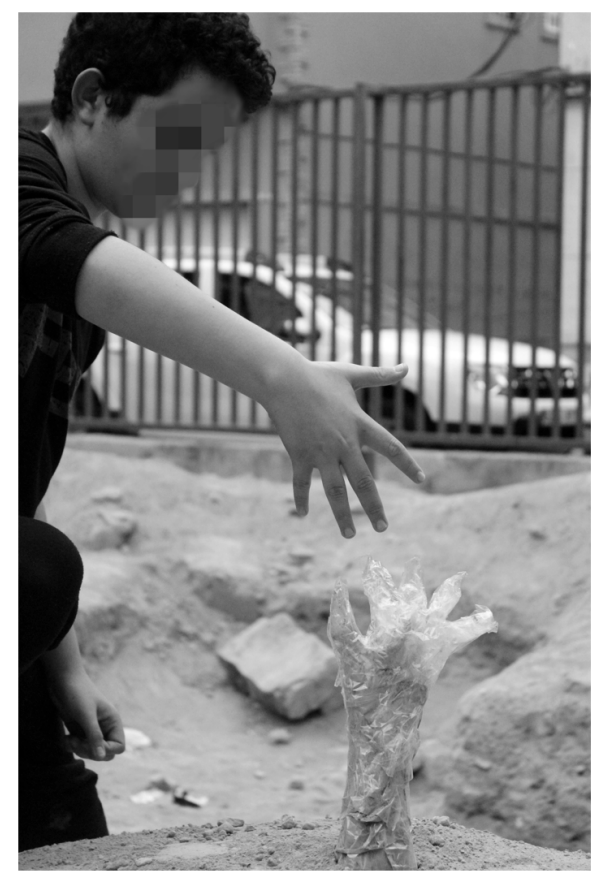

Figure 8. "The hand" (C). This sculpture, made by the students, represents the presence of the archaeologists and the local community in the "neutral" space of the site, exploring the concepts of memory and experience.

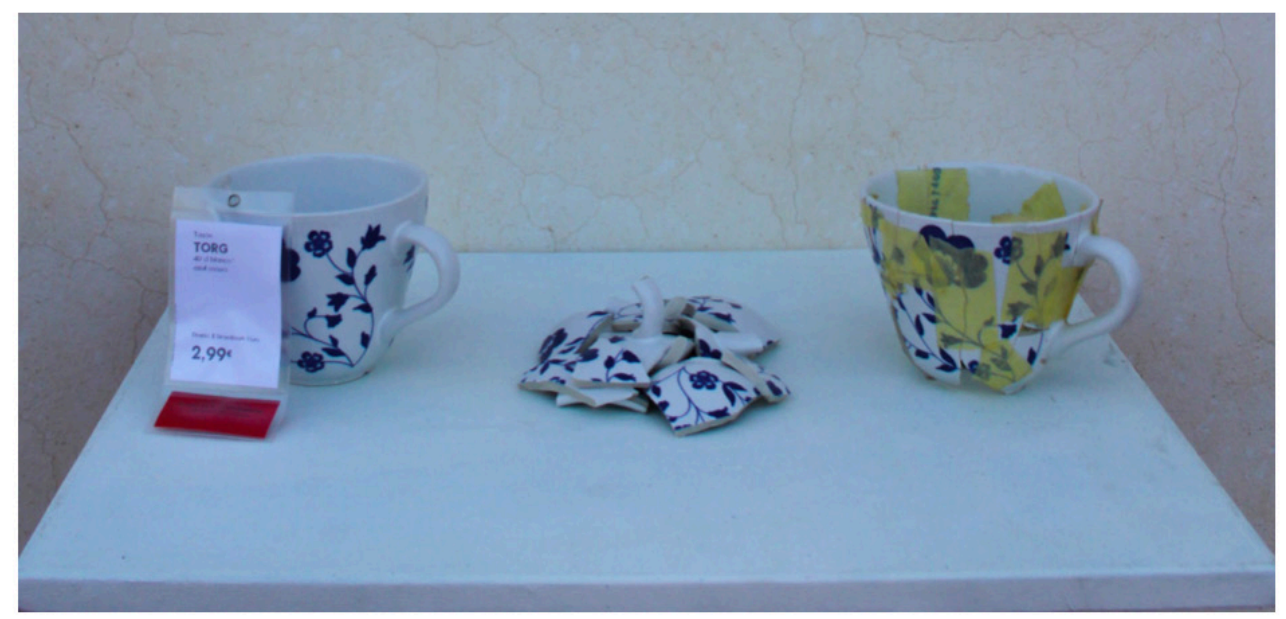

Figure 9. "Archaeological contra-museum". Aspect of the ceramics used in the simulated excavation in July 2016 prior to the construction of the site, during, and after the excavation. The one on the right was recovered and fixed by the students. 
108 - José A. MÁRMOL - Dropping the Trowel...

\section{Conclusions}

The development in recent years of the so-called 'creative archaeologies' has shown archaeology's ability to adapt and integrate reflections from other disciplines-although with the theoretical discussions overlooked, removing important agendas. The high number of young archaeologists has produced many interesting works, but following specific agendas and themes, such as periods, materials or technology applications. The advances in recent years have not necessarily changed the way we interact with the archaeological, although we have been able to integrate our reflections on public spaces a little better. All this does not happen only in archaeology, but we are in a formative moment of several movements like the new humanities, which are already clamouring for artistic and scientific multi-disciplinary fields of study in a world where a scientific paper is read by just ten people on average (Heleta 2016; Biswas \& Kirchherr 2015).

What I have proposed in this work is the transition from convergent thinking (based on questions with unique, specific answers, and considered correct), to divergent thinking, that is, questions that either do not have only one answer or have as many as each individual. The life experiences, academic backgrounds and works of archaeologists have a significant influence on how we do archaeology, and therefore what appears to be an objective science with questions, methods and answers, ends up being a melting pot of personal perspectives-some orthodox, other heterodox, some following general paradigms, other more alternative, which are only united by the academic demands and methodology (eminently visual, of process, aesthetic and certain environments), which, if followed, ensures the title of a 'work well done'. Therefore, it would not be entirely unreasonable to say that archaeology is an aesthetic methodology.

Although initially I talked about Chinese ceramics in Al-Andalus, the topic quickly led to a much broader discourse concerning our position in the world. The exposed story is a form of inspiration to integrate new temporal notions to our experience of the world. I remember the faces of the students in one of the courses of archaeology when we talked about the reason why the dishes are white, being poor imitations of Chinese porcelains from the 
medieval Islamic world. Suddenly, this puts those meanings in a more complete level with a dubious chronology, but largely negating many of the cultural, linguistic and racial frontiers between students.

Although it seems obvious, this narrative also makes us have another perspective on the past, this non-place. The creative reinterpretation of ceramics shows the intellectual value of the people of the past, which is commonly lost in the historical discourse of facts. It is surprising to understand that, in the memory of those objects, there is a capacity currently valued as creativity. These products, initially luxury goods for some minorities, were popularised with the appearance of imitations and products of 'popular' style for a 'mass' of potential buyers. And this phenomenon of popularisation eventually led to the adoption of the tableware that today we can see on our tables.

Finally, all this serves to be an active part in the process of resilience of the present. Artists that deal with the theme of memory, as Ai does, hold a discourse about a past that cannot connect with current reality. With the same tools, the artists also talk about current problems, such as in the case of Banksy on the refugee crisis in the Mediterranean, reaching with their reflections a huge audience through social networks. The question is, how can archaeology do the same? Can archaeologists, from the discourse of memory, help to solve problems of the present, and at the same time, redirect our discourse on materiality? It is not an easy task.

This example could make us think especially about the meanings and limits of our actions on heritage and on the dominant discourse. What differentiates Dropping Han Dynasty Urn and the destruction of the Mosul Museum by Daesh? For the future, there is a lot to do in the field of reflection on the use of culture (is culture destroying culture?), the value of archaeological heritage and its meanings, and the fact that the destruction of heritage, for example in the Middle East (e.g. the Buddhas of Bamiyan, Mes Aynak, Mosul, and Palmyra, among others) represents for local populations the disappearance of identity and spatial referents, while for us, the Western world, they become totems with high touristic and political values that they never possessed before. 
110 - José A. MÁRMOL - Dropping the Trowel...

Over the past few years we have been looking for alternative ways to theorise, interpret, intervene, document and disseminate our archaeological work. And now all these creative ways to 'see' archaeology are open to endless possibilities. At least for the next few years.

\section{References}

Ai Weiwei: Artistic license. 2012. The Economist. Retrieved from the WWW [http://www.economist.com/node/21554178].

Almansa, J. 2013. Arqueología pública en España. Madrid: JAS Arqueología.

Biswas, A. K. and Kirchherr, J. 2015. Prof, no one is reading you. The Straits Times. Retrieved from the WWW [http://www. straitstimes.com/opinion/prof-no-one-is-reading-you].

Bunyard, M. 2009. School children work as archaeologists. Primary History, 51, 27-28.

Castañeda, Q. E. 2008. The 'ethnographic turn' in archaeology: Research positioning and reflexivity in ethnographic archaeologies. In Q. E. Castañeda, and C. N. Matthews (eds.) Ethnographic archaeologies: Reflections on stakeholders and archaeological practices. Lanham: AltaMira Press, 25-62.

Castañeda, Q. E., and Matthews, C. N. (eds.). 2008. Ethnographic archaeologies: Reflections on stakeholders and archaeological practices. Lanham: AltaMira Press.

Carvajal, A., Hernando, C. and De los Reyes, M. 2011. El síndrome de Indiana Jones. La imagen social del arqueólogo. Estrat Crític, 5(3), 38-49.

Cohen, L. 2015. Ai Weiwei: A beginner's guide. The Royal Academy of Arts. Retrieved from the WWW [https://www.royalacademy. org.uk/article/ai-weiwei-beginners-guide].

Comendador, B. 2013. Consumo y mass media, la imagen especular del Pasado en la cultura popular. In Almansa, J. (ed.). Arqueología pública en España. Madrid: JAS Arqueología, 115-135. 
Edgeworth, M. 2003. Acts of discovery: An ethnography of archaeological practice. Oxford: British Archaeological Reports.

Edgeworth, M. 2010. On the boundary: new perspectives from ethnography of archaeology. In D. Garrow and T. Yarrow (eds.) Archaeology and Anthropology. Oxford: Oxford Books, 53-69.

Egea, A. and Arias, L. 2013. IES Arqueológico. La arqueología como recurso para trabajar las competencias básicas en la educación secundaria. Clío, 39. Retrieved from the WWW [http://clio.rediris.es]

Flannery, K. V. 1982. The golden Marshalltown: A parable for the archeology of the 1980s. American Anthropologist, 84(2), 26578.

Fraile Prieto, T. 2011. Propuestas para la investigación en comunicación audiovisual: publicidad social y creación colectiva en Internet. Tejuelo, 12, 156-72.

Friedrich, H. 1959. Estructura de la lírica moderna: De Baudelaire a nuestros días. Barcelona: Seix Barral.

Frigoli, R. 2012. Los intérpretes de Piteas: Una aproximación literaria al lenguaje, a la imagen y al trabajo de los arqueólogos. Madrid: JAS Arqueología.

García Roselló, J., Javaloyas Molina, D., Santacreu, D. A., and Calvo Trías, M. 2011. El aprendizaje en grupo fuera del aula: los talleres didácticos de Arqueología. Proceedings from Univest 2011: III Congrés Internacional Univest. Majorca: Universitat de les Illes Balears.

Gil, A., Izquierdo, M. I., Pérez, C., and Fiérrez, S. 1998. La experiencias didácticas del Taller de Arqueología 4 de Valencia. Proceedings from II Jornadas de Arqueología y Pedagogía. Barcelona: Museu d'Arqueologia de Catalunya.

González-Ruibal, A. 2012. Hacia otra Arqueología: Diez propuestas. Complutum, 23(2), 103-16.

González-Ruibal, A. (ed.). 2013. Reclaiming archaeology. Beyond the tropes of modernity. London: Routledge. 
112 - José A. MÁRMOL - Dropping the Trowel...

González, P. 2011. La dimensión educativa de la Arqueología. Proceedings from Congreso de Prehistoria de Andalucía. Andalusia: Consejería de Cultura.

Ham, S. 1992. Interpretación ambiental: Una guía práctica para gente con grandes ideas y presupuestos pequeños. Seattle: North American Press.

Hamilakis, Y. 2009. The 'war on terror' and the military-archaeology complex: Iraq, ethics, and neo-colonialism. Archaeologies, 5(1), 39-65.

Hamilakis, Y. 2014. Archaeology and the senses: Human experience, memory, and affect. Cambridge: Cambridge University Press.

Hamilakis, Y. 2015. Archeology and sensoriality. Towards an ontology of sets and flows. In Arqueología y los sentidos [Video file]. Retrieved from the WWW [https://www.youtube.com/ watch? $v=1 \mathrm{HZ}-6 \mathrm{~K}-7 \mathrm{Z6c}]$

Hamilakis, Y., and Anagnostopoulos, A. 2009. What is archaeological ethnography? Public archaeology, 8(2-3), 65-87.

Hamilakis, Y., Anagnostopoulos, A., and Ifantidis, F. 2009. Postcards from the edge of time: Archaeology, photography, archaeological ethnography (a photo-essay). Public archaeology, 8(2-3), 283309.

Hamilakis, Y., Pluciennik, M., and Tarlow, S. 2001. Academic performances, artistic presentations. Assemblage, 6. Retrieved from the WWW [http://www.assemblage.group.shef.ac.uk/ issue6/art_web.html]

Handler, R. 2008. A dangerously elusive method: Disciplines, histories, and the limits of reflexivity. In Q. E. Castañeda, and C. N. Matthews (eds.). Ethnographic archaeologies: Reflections on stakeholders and archaeological practices. Lanham: AltaMira Press, 95-118.

Heider, K. G. 1988. The Rashômon effect: When ethnographers disagree. American Anthropologist, 90(1), 73-81. 
Heleta, S. 2016. Academics can change the world-if they stop talking only to their peers. The Conversation. Retrieved from the WWW [http://theconversation.com/academics-can-change-theworld-if-they-stop-talking-only-to-their-peers-55713]

Hollowell, J., \& Nicholas, G. 2008. A critical assessment of ethnography in archeology. In In Q. E. Castañeda and C. N. Matthews (Eds.). Ethnographic archaeologies: Reflections on stakeholders and archaeological practices. Lanham: AltaMira Press, 63-94.

Holtorf, C. 2005. From Stonehenge to Las Vegas. Archaeology as a popular culture. Walnut Creek: Altamira Press.

Jiang, Q. Q. 2009. Tang sancai (Unpublished doctoral dissertation). University of Oxford, Oxford.

Le, My T. 2009. Culture matters: Contemporary art as a philosophy of society. Human Rights in China. Retrieved from the WWW [http://www.hrichina.org/en/content/3189]

Leone, M. P. 2008. The foundations of archeology. In Q. E. Castañeda and C. N. Matthews (eds.). Ethnographic archaeologies: Reflections on stakeholders and archaeological practices. Lanham: AltaMira Press, 119-138.

Li, Q. 2006. Maritime silk road. Beijing: Wu Zhuo Chuan Bo Press.

Mármol Martínez, J. A. 2014. La proyección de la imagen actual de la Arqueología y su importancia en divulgación con audiovisuales: observación y experimentación. Unpublished Master's dissertation. Universidad Autónoma de Madrid, Madrid.

Mármol Martínez, J. A., Muñoz Viñegla, M., and Marín López, M. A. 2015. De la excavación simulada al simulacro de excavación: la doble experiencia de alumnos y arqueólogos en un ejemplo de didáctica de la Arqueología. Proceedings from JIA 2015. Lisbon: Universidade Nova de Lisboa.

Matthews, C. N. 2008. The location of archeology. In Q. E. Castañeda and C. N. Matthews (eds.). Ethnographic archaeologies: Reflections on stakeholders and archaeological practices. Lanham: AltaMira Press, 157-182. 
114 - José A. MÁRMOL - Dropping the Trowel...

Meri, J. W. (ed.). 2005. Medieval Islamic civilization: An encyclopedia. London: Routledge.

Merriman, N. 2004. Diversity and dissonance in public archaeology. In Merriman, N. (Ed.). Public Archaeology. London: Routledge, 1-17.

Merriman, N. (Ed.) 200). Public archaeology. London: Routledge.

Millán Pascual, R. 2015. Arqueología negativa. Las fronteras arqueológicas del presente. Complutum, 26(1), 49-69.

Molina Gómez, J. A. 2008. A través del espejo: Preocupaciones contemporáneas por la paz mundial en el cine histórico sobre la Antigüedad. Proceedings from Congreso Internacional 'Imagines': La Antigüedad en las Artes escénicas y visuales. Logroño: Universidad de la Rioja.

Moser, S. 1998. Ancestral images: The iconography of human origins. Ithaca: Cornell University Press.

Pyburn, K. A. 2008. The pageantry of archology. In Q. E. Castañeda, \& C. N. Matthews (eds.). Ethnographic archaeologies: Reflections on stakeholders and archaeological practices. Lanham: AltaMira Press, 139-156.

Ramos, P., \& Torrico, J. P. 2006. Aula de arqueología del IES Humanes de Madrid. GazSEHA: Revista de la Sociedad Española de Historia de la Arqueología, 3, 15-9.

Rosenstone, R.A. 1997. El pasado en imágenes. El desafío del cine a nuestra idea de la historia. Barcelona: Ariel.

Ruiz Zapatero, G. 1998. Fragmentos del Pasado: La presentación de sitios arqueológicos y la función social de la Arqueología. Treballs d'Arqueologia, 5, 7-34.

Ruiz Zapatero, G. 2014. Fotografía y Arqueología: ventanas al pasado con cristales traslúcidos. Proceedings from Jose Latova. Cuarenta años de Fotografía arqueológica española. Madrid: Museo Arqueológico Regional.

Ruiz Zapatero, G. 2015. Escribir como arqueología. Arqueología como escritura. Anales de Prehistoria y Arqueología, 30. 11-28. 
Scolari, C. A. 2013. Narrativas transmedia: Cuando todos los medios cuentan. Bilbao: Deusto Editorial.

Shanks, M. 2004. Three rooms: Archaeology and performance. Journal of Social Archaeology, 4(2), 147-80.

Shanks, M. 2012. The archaeological imagination. Walnut Creek: Left Coast Press.

Shanks, M., and Pearson, M. 2001. Theatre/archaeology: Reflections on a hybrid genre. London: Routledge.

Shanks, M., and Svabo, C. 2013. Archaeology and photography: A pragmatology. In A. González-Ruibal (ed.). Reclaiming archaeology. Beyond the tropes of modernity. London: Routledge, 89-102.

Sullivan, M. 1999. The arts of China. Univ. of California Press.

Tejerizo, C. 2011. Archaeology and cinema: Distortions of a science and a profession. El Futuro del Pasado, 2, 389-406.

Tilley, C., Hamilton, S., \& Bender, B. (2000). Art and the re $\square$ presentation of the past. Journal of the Royal Anthropological Institute, 6(1), 35-62.

Olivier, L. 2008. Le sombre abîme du temps. Mémoire et archéologie. Paris: Seuil.

Valdés, F. 1991. Aspectos comerciales de la economía peninsular durante el periodo de los reinos de taifas. Cuadernos de Prehistoria y Arqueología, 18, 319-30.

Valdés, F. 1995. Datos sobre el comercio peninsular durante las primeras Taifas: El Reino de Badajoz. Proceedings from V Semana de estudios medievales: Nájera, 1 al 15 de agosto de 1994. La Rioja: Instituto de Estudios Riojanos.

Van Dyke, R. M. 2006. Seeing the past: Visual media in archaeology. American Anthropologist, 108(2), 370-5.

Whitehouse, D. 1972. Chinese porcelain in medieval Europe. Medieval Archaeology, 16, 63-78. 
Weebmor, T. 2005. Teotihuacán, Mexico. Mediating monumentality: An experiment. MetaArchaeology. Retrieved from the WWW [http://traumwerk.stanford.edu/teotihuacan].

Witmore, C. L. 2004. Four archaeological engagements with place mediating bodily experience through peripatetic video. Visual Anthropology Review, 20(2), 57-72.

Witmore, C. L. 2006. Vision, media, noise and the percolation of time symmetrical approaches to the mediation of the material world. Journal of Material Culture, 11(3), 267-92.

Wood, N. 1999. Chinese glazes: Their origins, chemistry, and recreation. Philadelphia: University of Pennsylvania Press.

Yap, C. 2012. "Devastating History." ArtAsiaPacific. Retrieved from the WWW [http://artasiapacific.com/Magazine/78/ DevastatingHistory]

Zimmerman, L. J. 2008. Real people or reconstructed people? Ethnocritical archeology, ethnography, and community building. In Q. E. Castañeda and C. N. Matthews (eds.). Ethnographic archaeologies: Reflections on stakeholders and archaeological practices. Lanham: AltaMira Press, 183-204.

Zozaya, J. 1970. Chinese porcelain in caliphal Spain. Colloquies on Art and Archaeology in Asia, 1, 54-7.

Zozaya, J. 1993. Dropping. Importaciones casuales en al-Andalus: las vías de comercio. Proceedings from IV Congreso de Arqueología medieval española. Alicante: Diputación Provincial. 